\title{
Potensi Ekstrak Sarang Semut sebagai Anthelmintik terhadap Ascaris suum secara In Vitro
}

\author{
(POTENTIAL EXTRACT ANT NEST AS AN ANTHELMINTIC OF ASCARIS SUUM IN \\ VITRO)
}

\author{
Cok Gde Agung Krishna Pemayun ${ }^{1}$, Anak Agung Gde Arjana ${ }^{2}$, I Made Dwinata* \\ ${ }^{1}$ Praktisi Dokter Hewan di Kecamatan Tampaksiring, Gianyar Bali. \\ ${ }^{2}$ Bagian Farmakologi dan Farmasi Veteriner, Fakultas Kedokteran Hewan, Universitas \\ Udayana, Jl. PB. Sudirman, Denpasar, Bali; \\ ${ }^{3}$ Laboratorium Parasitologi Veteriner, Fakultas Kedokteran Hewan, Universitas Udayana, Jl. \\ PB. Sudirman, Denpasar, Bali.*Email: made_dwinata@unud.ac.id
}

\begin{abstract}
Abstrak
Pengendalian parasit cacing dapat dilakukan dengan pemberian obat cacing, salah satunya dengan menggunakan obat tradisional. Salah satunya adalah sarang semut yang memiliki potensi antelmitik pada cacing Ascaris suum. Penelitian ini menggunakan cacing A. suum yang diperoleh dari RPH Pesanggaran, Denpasar kemudian ditumbuhkan secara in vitro. Sebanyak 90 ekor cacing yang terbagi menjadi 6 kelompok perlakuan dimana masing masing dosis menggunakan 5 ekor cacing. Kelompok P0 cacing yang direndam dengan $20 \mathrm{ml} \mathrm{NaCl}$ Fisiologis sebagain kontrol negatif, P1 kelompok cacing yang direndam dengan $20 \mathrm{ml} \mathrm{NaCl}$ Fisiologis dan di tambah albendazol 1\% sebagai control positif, P2 kelompok cacing yang direndam dengan larutan ekstrak sarang semut 5\%, P3 kelompok cacing yang direndam dengan larutan ekstrak sarang semut 10\%, P4 kelompok cacing yang direndam dengan larutan ekstrak sarang semut $15 \%$, P5 kelompok cacing yang direndam dengan larutan ekstrak sarang semut $20 \%$. Hasil yang diperoleh menunjukkan bahwa adanya peningkatan daya antelmintik ekstrak sarang semut terhadap cacing A. suum. Pada dosis ekstrak sarang semut $20 \%$ memiliki daya antelmintik yang sama dengan kontrol positif $(93,33 \%)$. Ekstrak sarang semut efektif sebagai obat cacing A. suum terbukti berkhasiat memiliki efek antelmintik sehingga dapat di kembangkan penggunaanya untuk pengendalian ascariasis pada babi.
\end{abstract}

Kata kunci: Babi; Ascaris suum; sarang semut

\begin{abstract}
Control of worm parasites can be done by administering worm medicine, one of them by using traditional medicine. One of them is an ant nest which has an anthelmintic potential in the A. suum worm. This study used A. suum worms obtained from Pesanggaran slaughterhouse, Denpasar and then grown in vitro. A total of 90 worms were divided into 6 treatment groups where each dose used 5 worms. Worm group P0 was soaked with $20 \mathrm{ml}$ Physiological $\mathrm{NaCl}$ as a negative control, $\mathrm{P} 1$ worm group soaked with $20 \mathrm{ml}$ Physiological $\mathrm{NaCl}$ and added $1 \%$ albendazole as positive control, $\mathrm{P} 2$ worm group soaked with 5\% ant nest extract solution, P3 soaked group of worms with a solution of $10 \%$ ant nest extract, the P4 group of worms was soaked with a solution of $15 \%$ ant nest extract, P5 of the worm group was soaked with $20 \%$ ant nest extract solution. The results obtained showed that there was an increase in anthelmintic power of ant nest extract against $A$. suum worms. At the dose of $20 \%$ ant nest extract has the same anthelmintic power with positive control (93.33\%). The ant nest extract is effective as an A. suum worm drug proven to have an anthelmintic effect so that its use can be developed to control ascariasis in pigs.
\end{abstract}

Keyword: Pig; Ascaris suum; sarang semut 


\section{PENDAHULUAN}

Populasi ternak babi di pulau Bali keberadaannya didominasi di daerah pedesaan yang sebagian besar dilakukan secara tradisional (Agustina et al., 2016a). Banyak kendala yang dihadapi untuk dapat meningkatkan usaha peternakan babi yang dipelihara dengan cara tradisional, salah satu kendala tersebut adalah babi yang peka terhadap infeksi berbagai jenis penyakit (Sihombing, 2006; Agustina et al., 2016b). Salah satu penyakit yang sering dijumpai pada babi adalah askariasis (Beriajaya, 1995). A. suum adalah parasit cacing yang menginfeksi babi, Prevalensi infeksi $A$. suum, pada babi pada daerah Bali mencapai 39\% (Yasa dan Guntoro, 2004) dan pada anak babi dilaporkan 33,2\% (Fendriyanto et al., 2017). Dampak yang ditimbulkan oleh infeksi parasit seperti cacing bagi ternak babi antara lain terjadinya diare, gastritis, anoreksia, penurunan berat badan, bahkan dapat mengakibatkan kematian, infeksi berat dapat menyebabkan penyumbatan di bagian duodenum atau jejunum secara total atau sebagian (Soulsby, 1982) serta potensi zoonosis (Agustina et al., 2017).

Pengendalian parasit cacing, dilakukan dengan pemberian obat cacing, Untuk mendapatkan efektivitas yang tinggi dalam pengobatan sebaiknya dilakukan identifikasi terlebih dahulu terhadap jenis cacing yang menginfeksi, kebanyakan obat cacing yang digunakan adalah obat yang berspektrum, Obat cacing memiliki kerja yang spesifik dan berbeda-beda untuk setiap jenis cacing nematoda, trematoda dan cestoda (Katzung, 2004). Untuk menanggulangi efek samping obat cacing modern yang berasal dari kimia sintetis, diperlukan obat yang berasal dari alam atau herbal. Salah satu obat alami adalah Sarang Semut, ditemukan di pulau Papua, banyak zat yang terkandung pada Sarang Semut, diantaranya flavonoid, dan tannin. (Natural 2006).

Potensi anthelmintic dari sarang semut disebabkan oleh flavonoid, karena dapat menyebabkan kematian cacing akibat denaturasi protein dalam tubuh cacing (Bhadoriya et al., 2011; Faradila, 2013). Penelitian ini bertujuan untuk mengetahui daya antelmintik ekstrak sarang semut terhadap cacing A. suum pada babi secara in vitro.

\section{METODE PENELITIAN}

\section{Obyek penelitian}

Obyek penelitian adalah cacing A. suum yang masih hidup di ambil dari usus halus babi yang dipotong di Rumah Pemotongan Hewan (RPH) yang berada di Pesanggaran, Denpasar, Bali. Kemudian cacing A. suum ditempatkan dalam botol yang berisi $\mathrm{NaCl}$ fisiologis.

\section{Rancangan Penelitian}

Rancangan penelitian menggunakan rancangan acak lengkap (RAL), Pada penelitian ini menggunakan 6 perlakuan dan 3 ulangan yaitu P0 (kontrol negatif tanpa ekstrak), P1 (kontrol positif dengan penambahan albendezol $1 \%$ ) P2 diberikan ekstrak sarang semut 5\%, P3 diberikan ekstrak sarang semut $10 \%$ P4 diberikan ekstrak sarang semut $15 \%$ dan P5 diberikan ekstrak sarang semut $20 \%$.

\section{Ekstraksi Sarang Semut}

Ekstraksi sarang semut dilakukan dengan sarang semut diperoleh dari Papua dalam bentuk utuh dan kering. Sebanyak 500gram serbuk tanaman sarang semut direndam kedalam 5 Liter Alkohol 70\% dan di diamkan selama 5 hari. Pada hari ke lima di lakukan penyaringan menggunakan kain flanel untuk memisahkan ampas dan ekstrak etanol tanaman sarang semut. Cairan ekstrak etanol tanaman sarang semut kemudian diuapkan menggunakan kompor listrik hingga tersisa ekstrak kental tanaman sarang semut.

\section{Perlakuan sampel}

Dosis ekstrak sarang semut dibuat menjadi $5 \%, 10 \%, 15 \%$ dan $20 \%$ dibuat dengan cara menimbang ekstrak masing masing sebanyak 5 gr, 10 gr, 15 gr dan 20 gr. Masing-masing hasil timbangan tersebut dilarutkan kedalam larutan $\mathrm{NaCl}$ 
0,9\% sebanyak $100 \mathrm{ml}$ dalam beker glass, kemudian dimasukkan kedalam cawan petrisesuai dengan dosis sebanyak $20 \mathrm{ml}$. setiap dosis perlakuaan diulang sebanyak 3 kali.

\section{Uji Anthelmintik}

Uji antelmintik ekstrak Sarang Semut terhadap cacing $A$. suum dilakukan dengan menggunakan 90 ekor cacing yang terbagi menjadi 6 kelompok perlakuan dimana masing masing dosis menggunakan 5 ekor cacing. Perlakuan dilakukan dengan merendam cacing pada masing masing dosis perlakuan dan pengamatan dilakukan setiap 30 menit sampai seluruh cacing mati. Kematian cacing dilihat dengan cara mengusik menggunakan batang pengaduk, bila cacing tidak bergerak cacing dianggap sudah mati.

\section{Analisis Data}

Data hasil penelitian diuji sidik ragam, dan hasil signifikan dilanjutkan dengan uji Duncan.

\section{HASIL DAN PEMBAHASAN}

\section{Hasil}

Pengaruh pemberian ekstrak sarang semut terhadap daya antelmintik terhadap cacing $A$. suum secara in vitro menunjukkan adanya efek yang dapat membunuh cacing A. suum. Hasil pengamatan daya antelmintik terhadap cacing $A$. suum secara in vitro dapat dilihat pada tabel 1 .

Tabel 1. Pengaruh daya antelmintik ekstrak sarang semut terhadap mortalitas cacing A. suum secara in vitro

\begin{tabular}{cccccc}
\hline Perlakuan & \multicolumn{5}{c}{ Rata-rata Konsentrasi Cacing Ascaris suum (\%) } \\
\cline { 2 - 6 } & 3 jam & 6 jam & 9 jam & 12 jam & 24 jam \\
\hline P0 & 0,00 & 0,00 & 0,00 & $0,00^{\mathrm{a}}$ & 0,00 \\
P1 & 20,00 & 53,33 & 73,33 & $93,33^{\mathrm{c}}$ & 100,00 \\
P2 & 0,00 & 20,00 & 40,00 & $46,67^{\mathrm{b}}$ & 66,67 \\
P3 & 0,00 & 20,00 & 53,33 & $53,33^{\mathrm{bc}}$ & 66,67 \\
P4 & 13,33 & 33,33 & 46,67 & $60,00^{\mathrm{bc}}$ & 73,33 \\
P5 & 13,33 & 46,67 & 73,33 & $93,33^{\mathrm{c}}$ & 100,00 \\
\hline
\end{tabular}

Ket: Huruf superskrip yang berbeda menyatakan berbeda nyata pada taraf $\mathrm{P}<0,05$

Hasil pemeriksaan daya antelmintik ekstrak sarang semut dengan berbagai dosis $(5 \%, 10 \%, 15 \%$, dan $20 \%)$ terhadap cacing A. suum menunjukkan adanya peningkatan daya antelmintik sesuai dengan meningkatkan dosis ekstrak sarang semut yang diberikan. Hasil uji sidik ragam menunjukkan adanya perbedaan yang nyata $(\mathrm{P}<0,05)$ antara kontrol dengan perlakuan. Kemudian dilanjutkan dengan uji Duncan yang juga menunjukkan adanya perbedaan nyata $(\mathrm{P}<0,05)$.

Pemeriksaan dilakukan selama 24 jam dan masing-masing diperiksa pada jam ke $3,6,9,12$, dan 24. Pada semua perlakuan menunjukkan adanya efek antelmintik yang semakin meningkat sesuai dengan meningkatkan dosis dan lama inkubasi. Pada dosis ekstrak sarang semut dosis $20 \%$ menunjukkan hasil yang sama dengan kontrol positif yaitu pemberian albendazole. Hal ini disebabkan karena ekstrak sarang semut mengandung senyawa flavonoid. Flavonoid memiliki potensi sebagao anthelmintik, karena dapat menyebabkan kematian cacing akibat denaturasi protein dalam tubuh cacing (Bhadoriya et al., 2011; Faradila, 2013).

\section{Pembahasan}

Pengendalian infeksi cacing A. suum selama ini bertumpu pada pemberian obat cacing (anthelmintik) yang dikombinasikan dengan sanitasi lingkungan sekitar ternak babi. Adanya kejadian resistensi cacing $A$. suum memacu para ahli untuk menemukan beberapa preparat anthelmintik baru, tidak terkecuali pemanfaatan obat-obat tradisional.

Menurut penelitian Susanti dan Prabowo (2015), yang meneliti mengenai 
tanaman Pinang (Areca catechu) yang memiliki kandungan hampir sama dengan sarang semut yaitu alkaloid, seperti tanin yang kemungkinannya mempunyai efek antelmintik. Senyawa tanin memiliki kemampuan menghambat enzim dan merusak membran. Membran yang rusak karena tanin menyebabkan paralisis yang akhirnya menyebabkan kematian. Bahan aktif Flavonoid adalah bahan aktif yang akan cepat diserap dan menyebabkan denaturasi. Senyawa-senyawa aktif seperti flavonoid, alkaloid, saponin, dan tanin pada tanaman obat cameroonian dan ghanian menurut Ndjonka et al. (2011) dapat menggangu pertumbuhan parasit filaria dan nematode. Senyawa-senyawa tersebut juga terkandung dalam ekstrak sarang semut. Efek senyawa seperti flavonoid, alkaloid, saponin, dan tanin dapat menyebabkan penggumpalan protein pada permukaan tubuh cacing Ascaris spp. dapat mengganggu metabolisme dan homeostasis tubuh cacing sehingga cacing akan mati (Syukron et al., 2014). Hal inilah yang menyebabkan adanyan pengaruh dosis dari setiap kelompok perlakuan dalam penurunan daya antelmintik cacing $A$. suum.

\section{SIMPULAN DAN SARAN}

\section{Simpulan}

Ekstrak sarang semut dapat memberikan efek antelmintik terhadap cacing A. suum secara invitro. Dosis ekstrak sarang semut sebesar $20 \%$ memiliki daya antelmintik yang paling kuat dengan efektifitas sebesar 93,33\% sebagai alternatif pengobatan infeksi cacing $A$. suum pada babi.

\section{Saran}

Perlu adanya penelitian lagi terhadap berbagai kandungan zat pada ekstrak sarang semut sehingga dapat diketahui khasiat lain dari ekstrak sarang semut. Ekstrak sarang semut $20 \%$ dapat digunakan sebagai pengobatan pada kasus ascariosis pada babi yang disebabkan oleh A. suum.

\section{UCAPAN TERIMAKASIH}

Penulis mengucapkan terimakasih banyak kepada Dekan Fakultas Kedokteran Hewan, atas fasilitas yang disediakan dalam melaksanakan penelitian ini.

\section{DAFTAR PUSTAKA}

Agustina KK, Dharmayudha AAGO, Oka IBM, Dwinata IM, Kardena IM, Dharmawan NS, Damriyasa IM. 2016a. Case of Entamoebiasis in pigs raised with a free range systems in Bali, Indonesia. J. Vet. 17(4): 570-575.

Agustina KK, Wirata IW, Dharmayudha AAGO, Kardena IM, Dharmawan NS. 2016b. Increasing farmer income by improved pig management systems. Buletin Vet. Udayana. 8(2): 122-127.

Agustina KK, Swacita IBN, Oka IBM, Dwinata IM, Traub RJ, Cargill C, Damriyasa IM. 2017. Reducing zoonotic and internal parasite burdens in pigs using a pig confinement system. Vet. World. 10(11): 1347-1352.

Beriajaya GA, Hartono SP. 1997. Pengaruh pemberian vermisidal terhadap jumlah telur cacing parasit pada ternak babi. Majalah Parasitol. Indonesia. 10(8): 8-17.

Bhadoriya SS, Uplanchiwar V, Mishra V, Ganeshpurkar A, Raut S, Jain KS. 2011. In vitro anthelmintic and antimicrobial potential of flavonoid rich fraction from Tamarindus indica seed coat. Pharmacol. Online. 3: 412-420.

Faradila A. 2013. Uji daya anthelmintik ekstrak etanol daun beluntas (Pluchea indica less) terhadap cacing gelang (Ascaris suum) secara in vitro. (Skripsi). Malang: Universitas Brawijaya.

Fendriyanto A, Dwinata IM, Oka IBM, Agustina KK. 2015. Identifikasi dan prevalensi cacing nematoda saluran pencernaan pada anak babi di Bali. Indonesia Med. Vet. 4(5): 465-473.

Katzung, BG. 2004. Basic \& Clinical Pharmacology. $9^{\text {th }}$ Ed. The McGrawHill Companies. United State. 
Natural. 2006. Senyawa Aktif Bersarang di Sarang Semut. Majalah. Jakarta, Pp. 1819.

Ndjonka D, Agyare C, Lüersen K, Djafsia B, Achukwi D, Nukenine EN, Hensel A, Liebau E. 2011. In vitro activity of cameroonian and Ghanaian medicinal plants on parasitic (Onchocerca ochengi) and free-living (Caenorhabditis elegans) nematodes. $J$. Helminth. 85: 304-312.

Sihombing. 2006. Ilmu Ternak Babi. Edisi Kedua. Yogyakarta: UGM Press. Pp. 1115.

Soulsby EJL. 1982. Helminths, Arthropods, and Protozoa of Domesticated Animals Seventh Edition. London: Balliere. P: 809.

Susanti AE, Prabowo A. 2015. Potensi pinang (Areca catechu) sebagai untuk ternak. Prosiding Seminar Nasional Pertanian Ramah Lingkungan Mendukung Bioindustri di Lahan Sub Optimal Palembang, 16 September 2014.

Syukron MU, Damriyasa IM, Suratma NA. 2014. Potensi serbuk daun kelor (Moringa oleifera) sebagai anthelmintik terhadap infeksi Ascaris suum dan feed supplement pada babi. $J$. Ilmu dan Kesehatan Hewan. 2(2): 8996.

Yasa R, Guntoro S. 2004. Prevalensi infeksi cacing gastrointestinal pada babi (studi kasus pada pengkajian penggemukan babi) di Desa Sulahan Kecamatan Susut Kabupaten Bangli. Denpasar, Balai Pengkajian Teknologi Pertanian Bali. 